\title{
EFFECTS OF OCCUPATIONAL HEALTH AND SAFETY LAW ON FORESTRY EMPLOYEES
}

\author{
INANÇ, S. $^{1^{*}}-$ AGYÜREK, C. ${ }^{2}$ \\ ${ }^{1}$ Faculty of Forestry, Artvin Çoruh University, Artvin, Turkey \\ ${ }^{2}$ Directorate of Eastern Anatolia Forestry Research Institute, Erzurum, Turkey \\ *Corresponding author \\ e-mail: inanc_sevim@hotmail.com; phone: +90-532-440-8691, +90-542-481-7698
}

(Received 24 $4^{\text {th }}$ Jan 2019; accepted $8^{\text {th }}$ Mar 2019)

\begin{abstract}
Forest covering $28.6 \%$ of Turkey is an important area of employment. In this study, the awareness of the employees of Erzurum Forest Nursery Directorate has been attempted to be investigated by applying the Law No. 6331 on occupational health and safety. In the study, a questionnaire consisting of 36 independent questions, 8 independent and 28 dependent variables were prepared. The data obtained from the questionnaires was evaluated in the SPSS 20.0 program, and frequency distributions were determined. In addition, Chiropractic Analysis was performed to see if there is a statistical relation between dependent and independent variables in the questionnaires. According to the results; the ratio of General Occupational Health and Safety Education is $82.3 \%$. However, the percantage of those using Personel Protective Equipment was lower 70.5\%. Nearly all of those who stated that they had health problems in the institution were married women over the age of 40 . If these groups are generally considered to be physically active and do not have job descriptions, the measures to be taken are: To ensure that dangerous situations affecting the health of employees are identified and removed from the scene by means of the risk assessment team established in accordance with Law No. 6331 on occupational health and safety.
\end{abstract}

Keywords: forest workers, nursery workers, Law No. 6331, occupational health and safety, personal protective equipment

\section{Introduction}

Providing legal protection to all employees to protect their rights that arise from work life is a requirement of the principle of social law state (Kılıç, 2006). Forestry employees working in forestry sector have been deprived of the legal protection that is normally provided by the Labor Law for many years.

Although partly, forestry employees have been included in the Turkish Labor Law for the first time with the Law 4773, which is also known as the Law on Job Security. However, since emerging new concepts that have appeared with the international commitments of Turkey and since the Law 1475 remained insufficient in covering today's needs in work life, the Law 4857, which was enacted in 2003, has taken its place as the basic law of labor legislation. The Law 4857 expanded the scope of Law 1475 by significantly changing it, and now it is a modern Labor Law with new principles and amendments it brought.

With some limitations, forestry employees were also included in Labor Law 4857 and in the regulations issued in accordance with this Law. Although there are limitations, it must be considered as an important step taken in this area for the legal protection of forestry employees (Engür, 2014).

In forestry sector, compared to other sectors, because of the fact that seasonal employment is excessive and employment status is temporary, many problems 
preventing the establishment and management of an insurance system have become inevitable; and the social security of the employees in this sector has not been established completely. This situation has been an obstacle for the necessary care to be taken for the implementation of relevant measures in terms of occupational accidents and diseases (Tunay and Emir, 2015).

The occupational health and safety issue constitute a very important aspect of today's business life and labor law. Occupational health and safety measures intend to ensure that occupational accidents and diseases do not occur or are reduced to an acceptable level.

The most important factor making businesses successful or unsuccessful is the human factor. Based on this understanding, an increasing interest has emerged in the psychological and physical conditions of employees and their behaviors related to their jobs. People spend most of their time at work; and the productivity increases as much as they can be happy at work. For this reason, the importance of the occupational health and safety concept is increasing with each passing day (Zorlu, 2008).

Parallel to the industrialization of countries, the problem of ensuring that employees work in health and safety has emerged as one of the most important problems that need to be solved. The concern for not making employees pay for the cost of industrialization and technological developments that are benefited by all people in the society constitutes one of the main aims of contemporary societies (Ekin, 2009).

The purposes of the studies conducted on occupational health and safety may be listed as follows;

- Protecting Employees.

- Contributing to Create Safe Working Environments.

- Ensuring the Productivity of Working is Achieved.

- Providing Opportunities for Employees to Sustain Their Work Lives (Bayılmış, 2013).

For this reason, investments made on the measures intended to ensure occupational health and safety will help to protect the health and safety of employees, avoid occupational risks, eliminate the risk and accident factors, and improve the health and safety conditions continuously at workplaces (Oğuz, 2010).

It is a fact that occupational health and safety measures can only become effective with joint understanding of employees, employers and the state. However, when forestry sector is compared with other sectors, it is clear that this triple mechanism has not gone beyond creating awareness. This situation stems from the different characteristics of forestry business in terms of work life, and prevents the implementation of the provisions of the Law on Occupational Health and Safety in this field (Tunay and Emir, 2015).

According to Poschen (1993), ILO defined forestry activities as "3-D" profession, in other words, a dirty, difficult, and dangerous work (Menemencioğlu, 2006). When this is considered, it becomes compulsory for forest employees to be careful, practical, intelligent, think in a sophisticated manner, be healthy, endure with effective body structure, have appropriate equipment at work, love the nature and walking, and be responsible people (Acar and Şentürk, 1997).

In this study, the purpose was to evaluate the effect of Occupational Health and Safety Law 6331 on forest employees who work under difficult conditions. For this reason, Erzurum Forest Tree-nursery Directorate was chosen as the Study Area; and the effects of the Occupational Health and Safety law on the awareness levels of the nursery employees were examined. 


\section{Material and Method}

\section{The case study area}

The material of the study consisted of 102 nursery personnel who worked at the 4 Forest Nurseries in Erzurum Forest Nursery Directorate, and Questionnaire forms that consisted of 36 questions. In addition, previous studies in the literature that were conducted in this field and the records of Erzurum forest nursery directorate were also made use of.

Erzurum Regional Directorate of Forestry of which the Erzurum Forestry Nursery Directorate is the sub-unit, and which is selected as the Study Area, covered the cities of Erzurum, Erzincan, Kars, Ardahan, Iğdır and Ağrı consisting of 10 forest management directorates of Erzurum, Oltu, Şenkaya, Erzincan, Refahiye, Kars, Sarıkamış, Ardahan, Iğdır and Ağrı. Nearly 2.6\% of Turkey's population lives in this region (TUİK, 2018). Acording to General Directorate of Forestry (GDF) records, the total area of the region is 8.849.193 ha, about 5\% of which forested (GDF, 2018).

In the study area, the high amount of the area that is the subject to forestation is noteworthy. In the area, 5000 ha forestation and 8000 ha erosion control works are performed. These activities constitute the most important forestry activity of the area. To cover the need of seedlings that are used in the forestation and erosion control works in the area, there are 4 nursery engineering units (Sarıkamış, Ağrı, Erzincan and Erzurum), with their headquarters in Erzurum with a capacity of 20 million seedlings a year. A total of 102 employees work in these units.

\section{Sampling method}

The data obtained from the face-to-face questionnaires that were carried out with 102 employees in the nurseries, which were included in the study, were converted into a matrix in computer medium. This matrix was made by encoding the answers that were given to each question in numbers. The matrix that was generated from the encoding was analyzed in the SPSS 20.0 Program; and the frequency distributions were determined. As the data did not show normal distribution, the Chi Square $\left(\chi^{2}\right)$ Analysis was made to determine whether there were statistically significant relations between the dependent and independent variables in the questionnaires. The analyzes were carried out by employing the SPSS 20.0 Program.

\section{Results}

Erzurum Forestry Directorate has nursery engineering units in Erzurum, Erzincan, Erzincan, Ağrı and Sarıkamış. As it may be understood in the data given in Table 1 below, the number of people who participated in the questionnaire was 102. It was understood that there were no employees in Ağrı Engineering Unit. It was also understood that many of the employees (66\%) were employed in Erzurum Nursery Engineering Unit.

It was understood in the analyses of the questionnaires that a total of $9.8 \%$ of the nursery employees were female; and $90.2 \%$ were male. In addition, it was also determined that $6.9 \%$ of the employees were literate, $26.5 \%$ were primary school graduates, $45.1 \%$ of were secondary education graduates, $21.6 \%$ had undergraduate and post-graduate education levels. When the ages of the nursery employees were examined, it was determined that the highest rate was $39.2 \%$ in the $41-50$ age group. 
Table 1. Demographic situations of forest nursery workers

\begin{tabular}{|c|c|c|c|c|c|c|}
\hline & & \multicolumn{5}{|c|}{ Forest Nursery Engineering } \\
\hline & & Erzurum & Erzincan & Sarıkamış & Others & Total \\
\hline \multirow{2}{*}{ Gender } & Female & 2 & 7 & - & 1 & 10 \\
\hline & Male & 65 & 12 & 4 & 11 & 92 \\
\hline \multirow{2}{*}{ Marital status } & Single & 8 & 4 & 2 & 2 & 16 \\
\hline & Married & 59 & 15 & 2 & 10 & 86 \\
\hline \multirow{5}{*}{ Age group } & $15-18$ & 1 & - & - & - & 1 \\
\hline & $19-30$ & 9 & 2 & 1 & - & 12 \\
\hline & $31-40$ & 7 & 4 & 2 & 5 & 18 \\
\hline & $41-50$ & 30 & 7 & - & 3 & 40 \\
\hline & $50+$ & 20 & 6 & 1 & 4 & 31 \\
\hline \multirow{5}{*}{$\begin{array}{l}\text { Education } \\
\text { status }\end{array}$} & Literate & 5 & 2 & - & - & 7 \\
\hline & Primary & 16 & 11 & - & - & 27 \\
\hline & Secondary & 38 & 3 & - & 1 & 46 \\
\hline & Undergraduate & 7 & 3 & 4 & - & 17 \\
\hline & Postgraduate & 1 & - & - & 2 & 5 \\
\hline \multirow{5}{*}{ Title } & Manager & - & - & - & 1 & $\mathbf{1}$ \\
\hline & Engineer & 3 & 2 & 1 & 1 & 9 \\
\hline & Officer & 8 & 1 & - & - & 12 \\
\hline & Worker & 52 & 16 & 2 & 1 & 74 \\
\hline & Others & 4 & & 1 & 2 & 6 \\
\hline \multirow{4}{*}{$\begin{array}{l}\text { Work done de } \\
\text { facto }\end{array}$} & Body worker & 31 & 10 & 1 & - & 44 \\
\hline & $\begin{array}{c}\text { Fertilization, } \\
\text { spraving }\end{array}$ & 1 & - & - & - & 1 \\
\hline & Driver & 20 & 5 & 1 & - & 27 \\
\hline & Office worker & 15 & 4 & 2 & - & 30 \\
\hline
\end{tabular}

The fact that the rate of the participants saying "Yes" to the question "Is OHS training necessary?" at a rate of $95 \%$ clearly shows that these trainings are necessary for the employees (Table 2). All women believe that training is necessary. When the physical conditions of the workplace and the OHS culture of the employees were compared before and after the enacted law, it is possible to claim that the OHS culture improved at a significant level.

The nursery employees who thought that the trainings on the OHS Law 6331 was necessary believe that it would be adequate if these trainings were organized once a year at a rate of $20.6 \%$; and $6.9 \%$ believed that there is no need for these trainings; $69.6 \%$ believed that these trainings should be organized every 6 months; $2.0 \%$ believed that these trainings should be organized every 3 years; and $1 \%$ believed that these trainings should be organized every 5 years. Such trainings should be organized in each month of the year; and the OHS issue should be kept active on the agenda of employees. It is considered that in this way, a contribution will be made to the development of OHS culture; and the demands of the employees will be covered.

Nursery employees were asked whether the OHS trainings they participated in covered the nursery issues or general OHS issues; and the employees stated that the issues were on nursery issues at a rate of $32.4 \%$. In this context, $15.7 \%$ stated that the issues were on general forestry issues; $39.2 \%$ stated that the issues were on basic OHS issues; and $12.7 \%$ answered as "None" to this question. The distribution of the answers in this context shows that the employees have demands on the work they do, which is also a sign that they care about this issue.

After the Law No. 6331 on Occupational Health and Safety was enacted, and after the trainings, the employees were asked "Have you experienced any changes in your work life?". The answer to this question was "Yes" at a rate of $80 \%$. A total of those 
who said "Yes" to this question said "Our working environment became safer" at a rate of $21.6 \% ; 19.6 \%$ of the participants said "We were given more care by our employers"; $17.6 \%$ said "Our work started to be more regular and systematic"; and 17.6\% said "We started to use personal protective equipment". The fact that there were very positive answers at a rate of $80 \%$ to the questionnaire shows that positive and valuable feedbacks are received about the law. Here, we see that male employees said "Yes" at a higher percentage than female employees.

Table 2. Occupational health and safety knowledge level of forest nursery workers

\begin{tabular}{|c|c|c|c|c|c|c|}
\hline & \multicolumn{2}{|c|}{ Yes } & \multicolumn{2}{|c|}{ No } & \multicolumn{2}{|c|}{ Total } \\
\hline & Female & Male & Female & Male & Yes & No \\
\hline $\begin{array}{l}\text { Do you have a written job description with } \\
\text { clear and defined boundaries? }\end{array}$ & 2 & 51 & 8 & 41 & 53 & 49 \\
\hline $\begin{array}{c}\text { Is your opinion applied in the arrangements } \\
\text { regarding the working place and working } \\
\text { conditions? }\end{array}$ & 2 & 52 & 8 & 40 & 54 & 48 \\
\hline Are adequate security measures taken? & 5 & 76 & 5 & 14 & 81 & 19 \\
\hline $\begin{array}{c}\text { Do you participate in studies outside the } \\
\text { nursery? }\end{array}$ & 2 & 10 & 8 & 82 & 12 & 90 \\
\hline $\begin{array}{c}\text { Do you have a transport limit during } \\
\text { operation? }\end{array}$ & 1 & 40 & 9 & 52 & 41 & 61 \\
\hline $\begin{array}{l}\text { Do you take personal protective measures } \\
\text { when working with substances that threaten } \\
\text { human health? }\end{array}$ & 2 & 12 & 8 & 80 & 14 & 88 \\
\hline $\begin{array}{c}\text { Do you think that the way you transport and } \\
\text { store the chemical substances you use is done } \\
\text { in accordance with the occupational safety } \\
\text { rules? }\end{array}$ & 1 & 24 & 9 & 68 & 25 & 77 \\
\hline $\begin{array}{l}\text { Have the necessary training been given to } \\
\text { transport, storage and use of chemicals? }\end{array}$ & 2 & 28 & 8 & 64 & 30 & 72 \\
\hline $\begin{array}{l}\text { Do you have any health problems that you } \\
\text { think arises from nursery work? }\end{array}$ & 8 & 13 & 2 & 79 & 21 & 81 \\
\hline $\begin{array}{c}\text { Do you have any currently diagnosed chronic } \\
\text { diseases? }\end{array}$ & 7 & 9 & 3 & 77 & 16 & 86 \\
\hline $\begin{array}{l}\text { Are personal protective equipment suitable for } \\
\text { your work? }\end{array}$ & 4 & 56 & 6 & 36 & 60 & 42 \\
\hline $\begin{array}{l}\text { Do you use the personal protective equipment } \\
\text { that you use to maintain and maintain the work } \\
\text { properly? }\end{array}$ & 2 & 80 & 8 & 12 & 82 & 20 \\
\hline $\begin{array}{l}\text { Did you experience any occupational accidents } \\
\text { or diseases after you entered work? }\end{array}$ & 2 & 23 & 8 & 69 & 25 & 77 \\
\hline $\begin{array}{l}\text { Have you received basic training in } \\
\text { Occupational Health and Safety? }\end{array}$ & 10 & 8 & - & 84 & 18 & 84 \\
\hline Do you think OHS trainings are necessary? & 10 & 85 & - & 7 & 95 & 7 \\
\hline $\begin{array}{c}\text { Have you been informed about how to safely } \\
\text { and correctly use equipment equipment in the } \\
\text { nursery in OHS trainings? }\end{array}$ & 10 & 77 & - & 15 & 87 & 15 \\
\hline $\begin{array}{l}\text { Is training on effective use of personal } \\
\text { protective equipment provided? }\end{array}$ & 10 & 62 & - & 30 & 72 & 30 \\
\hline $\begin{array}{c}\text { After the entry into force of the Occupational } \\
\text { Health and Safety Law No. 6331, and after the } \\
\text { trainings, have you experienced any changes } \\
\text { in your working life? }\end{array}$ & 6 & 74 & 4 & 18 & 80 & 22 \\
\hline $\begin{array}{c}\text { Do you think there is a decrease in the number } \\
\text { of occupational accidents and occupational } \\
\text { diseases in the nursery after the entry into } \\
\text { force of the Occupational Health and Safety } \\
\text { Law No. 6331? }\end{array}$ & 10 & 80 & - & 12 & 90 & 12 \\
\hline
\end{tabular}




\section{The relation between gender, workplace and working conditions}

In the answers that were given to the question "Is your opinion asked about the regulations about your work place and working conditions?", it was examined whether there were statistically significant differences between the genders (female/male); and it was determined that there were significant differences (Table 3). According to this result, there is a statistically significant relation between working conditions and gender variable.

Table 3. Relationship between gender and workplace and working conditions

\begin{tabular}{c|cc|cc}
\hline \multirow{2}{*}{$\begin{array}{c}\text { Workplace and } \\
\text { Conditions }\end{array}$} & \multicolumn{2}{|c}{ Female } & \multicolumn{2}{c}{ Male } \\
\cline { 2 - 5 } & Number of people & $\%$ & Number of people & $\%$ \\
\cline { 2 - 5 } Yes & 2 & 20.0 & 52 & 56.5 \\
No & 8 & 80.0 & 40 & 43.5 \\
Total & 10 & 100.0 & 92 & 100.0 \\
\hline
\end{tabular}

Chi Square $=13.812 ;$ sd $2 ; 0.01<0.05$

\section{The relation between the work done de facto and security measures}

The employees were asked "Are adequate security measures taken at the unit where you work?". It was examined whether there were statistically significant differences between the work done de facto (body employees, fertilization, drug-spraying employees, packaging and sales employee, drivers and office employees) in the answers given to this question, and significant differences were detected as a result of the analyses (Table 4). A statistically significant relation was detected between the dependent variable "Are adequate safety measures taken at the unit where you work?" and the independent variable "the work done de facto".

Table 4. The relation between work done de facto and security measures

\begin{tabular}{|c|c|c|c|c|c|c|c|c|}
\hline \multirow{3}{*}{$\begin{array}{l}\text { Security } \\
\text { Measures }\end{array}$} & \multicolumn{8}{|c|}{ Work Done De Facto } \\
\hline & \multicolumn{2}{|c|}{ Body worker } & \multicolumn{2}{|c|}{ Fertilization, spraying } & \multicolumn{2}{|c|}{$\begin{array}{c}\text { Packaging sales } \\
\text { employee }\end{array}$} & \multicolumn{2}{|c|}{$\begin{array}{c}\text { Driver and office } \\
\text { worker }\end{array}$} \\
\hline & $\begin{array}{c}\text { Number of } \\
\text { people }\end{array}$ & $\%$ & $\begin{array}{l}\text { Number of } \\
\text { people }\end{array}$ & $\%$ & $\begin{array}{l}\text { Number of } \\
\text { people }\end{array}$ & $\%$ & $\begin{array}{l}\text { Number of } \\
\text { people }\end{array}$ & $\%$ \\
\hline Yes & 30 & 68.2 & 0 & 0.0 & 23 & 85.2 & 28 & 93.3 \\
\hline No & 14 & 31.8 & 1 & 100.0 & 4 & 14.8 & 2 & 6.7 \\
\hline Total & 44 & 100.0 & 1 & 100.0 & 27 & 100.0 & 30 & 100.0 \\
\hline
\end{tabular}

Chi Square $=13.896 ;$ sd 6; $0.031<0.05$

\section{The relation between the work done de facto and health problems}

The employees were asked "Do you have any health problems that you think stem from the nursery work?". It was examined whether there were statistically significant differences between the work done de facto (body employees, fertilization, drugspraying employees, packaging and sales employee, drivers and office employees) in the answers given to this question, and significant differences were detected as a result of the analyses (Table 5). In the answers given by the employees to the question, "Do you have any health problems that you think stemming from the nursery work?" which 
was under the title of "the health conditions of the employees", a statistically significant relation was detected between this dependent variable and the independent variable (the work done de facto).

Table 5. The relation between work done de facto and health problems

\begin{tabular}{|c|c|c|c|c|c|c|c|c|}
\hline \multirow{3}{*}{$\begin{array}{c}\text { Health } \\
\text { Problems }\end{array}$} & \multicolumn{8}{|c|}{ Work Done De Facto } \\
\hline & \multicolumn{2}{|c|}{ Body worker } & \multicolumn{2}{|c|}{ Fertilization, spraying } & \multicolumn{2}{|c|}{ Driver } & \multicolumn{2}{|c|}{ Office worker } \\
\hline & $\begin{array}{c}\text { Number of } \\
\text { people }\end{array}$ & $\%$ & $\begin{array}{c}\text { Number of } \\
\text { people }\end{array}$ & $\%$ & $\begin{array}{c}\text { Number of } \\
\text { people }\end{array}$ & $\%$ & $\begin{array}{l}\text { Number of } \\
\text { people }\end{array}$ & $\%$ \\
\hline Yes & 13 & 29.5 & 0 & 0.0 & 7 & 25.9 & 1 & 3.3 \\
\hline No & 31 & 70.5 & 1 & 100.0 & 20 & 74.1 & 29 & 96.7 \\
\hline Total & 44 & 100.0 & 1 & 100.0 & 27 & 100.0 & 30 & 100.0 \\
\hline
\end{tabular}

Chi Square $=16.849 ;$ sd 6; $0.01<0.05$

\section{The relation between the educational status and $\mathrm{OHS}$ basic trainings}

It was examined in the answers given to the question whether there was a statistically significant difference between the educational status (literate, elementary, secondary, faculty and postgraduate or doctorate level) and it was found that there was a significant difference in the answers given to the question "Have you received basic training on occupational health and safety?" (Table 6). A statistically significant relation was detected between the dependent variable "Have you received OHS Basic Training?", which is under the title "Evaluation of Existing OHS Trainings", and the independent variable "educational status", which is under the "general information about employees" heading.

Table 6. The relationship between educational status and OHS basic trainings

\begin{tabular}{|c|c|c|c|c|c|c|c|c|c|c|}
\hline \multirow{3}{*}{$\begin{array}{c}\text { OHS Basic } \\
\text { Training }\end{array}$} & \multicolumn{10}{|c|}{ Educational Status } \\
\hline & \multicolumn{2}{|c|}{ Literate } & \multicolumn{2}{|c|}{ Primary } & \multicolumn{2}{|c|}{ Secondary } & \multicolumn{2}{|c|}{ Under graduate } & \multicolumn{2}{|c|}{ Post graduate } \\
\hline & $\begin{array}{l}\text { Number } \\
\text { of people }\end{array}$ & $\%$ & $\begin{array}{l}\text { Number } \\
\text { of people }\end{array}$ & $\%$ & $\begin{array}{l}\text { Number } \\
\text { of people }\end{array}$ & $\%$ & $\begin{array}{l}\text { Number } \\
\text { of people }\end{array}$ & $\%$ & $\begin{array}{l}\text { Number } \\
\text { of people }\end{array}$ & $\%$ \\
\hline Yes & 3 & 42.9 & 25 & 92.6 & 37 & 60.9 & 14 & 82.4 & 5 & 100 \\
\hline No & 4 & 57.1 & 2 & 7.4 & 9 & 19.6 & 3 & 17.6 & 0 & 0,0 \\
\hline Total & 7 & 100 & 27 & 100 & 46 & 100 & 17 & 100 & 5 & 100 \\
\hline
\end{tabular}

Chi Square=16.386; sd 8; $0.037<0.05$

\section{Discussion}

According to the study results, it was observed that the Nursery Directorate did not employ women over 40 years of age who had relatively low educational levels at jobs that required muscle strength; and instead, women were generally employed in more physical works like removing weeds or hoeing preferably in the nursery field, which do not relatively require training and qualifications to increase their productivity. In addition, the fact that there were no job definitions for women is considered as a condition that needs correction by the nursery directorate.

It was observed that single employees who were under the age of 40 and who had low education levels were preferably employed in physical works outside the nursery. In addition, it was also determined as a negative situation in terms of work efficiency and safety that married women who were older than 40 years of age and who had low 
educational levels thought that they could not rest with regular intervals. Here, it may be understood that the provisions stated in the labor legislation and the current Collective Labor Agreement (CLA) are not covered in the workplace. When the working years of these groups were examined, it was observed that many of them had been doing the same work at the same workplace for more than 15 years.

It was also observed that since the drivers and office employees worked in closer positions to the management staff, their job descriptions were made in general. It is considered that since the drivers and office employees share the same medium with the administrators, and as they are close and necessary for the job they do, they read and understand the business legislation and CLA, their job descriptions are made, and they are given more place in the management and in the organization. It is also considered that they are more satisfied with their jobs because of their proximity to decisionmakers and due to the more comfortable working environment compared with other groups. Unfortunately, this comfort is relatively seen in the work environment where employees work with their physical strengths. This situation is the opposite in employees who work in the field, and creates dissatisfaction. To eliminate this, more trainings, seminars and information meetings must be held. In addition, the work done by employees must be defined, in other words, the work must not be in an open-ended structure.

When the health status of the employees working at the nursery was examined, it was considered that women face more health problems compared to men, which is considered to be due to the fact that they work in more bodily works. It is necessary that women employees are made to use the personal protective equipment that is provided to them and their working conditions are improved.

When the surgery status of the employees was considered, it was seen that the employees who had higher education levels had more surgeries. It is considered that employees who had high education levels took both reactive and proactive measures and treatments, and those who had low education levels might not have reached the adequate level in terms of awareness in this respect.

It was noteworthy that female employees who were above the age of 40 stated that they were dissatisfied with the suitability of their KKDs to the work, and that they had very low occupational accident rates; however, they had health problems. Although their work involves bodily work, it is possible that they have occupational diseases rather than occupational accidents. They might especially have diseases like muscle and joint disorders. In addition to this, the employees who had primary and secondary education levels also considered that the KKD that was provided to them was inappropriate. It is considered that this group has a relatively higher rates in terms of work accidents. The high risk of occupational accidents in this group might be associated with the fact that they do work that require physical strength. The groups that have high work accident rates may be listed as follows; the male employees who had been working at Erzurum and Sarıkamış nurseries for more than 15 years. Many of these employees work with physical strength.

According to the mandatory provision of the OHS Law 6331, it is compulsory to provide employees with basic OHS trainings in accordance with the danger class of their works; however, the rate of those who declared that they were not provided with any trainings in the institution was $17.6 \%$. It was determined in the files that the training programs were organized previously. It was seen that those who were married and who 
were over 40 years of age complained more about the inadequacy of training on tools, equipment and correct use of KKD.

The entire master and doctorate education groups and most of the faculty group said "Yes" to the question on whether the basic trainings of OHS were received. The highest rate of those who said "No" is secondary education and literate group. The rate of saying "No" in secondary education is $50 \%$. It was seen in the distribution of the training subjects that the employees made evaluations on the general OHS and the work they did. This demand complies with the legislation. In the answers that were given to the question about the correct use of tools, equipment and KKD, it was seen that as the education level increased, the satisfaction also increased. In general, the employees who were elderly, women, married and had low education levels were dissatisfied with this issue.

The office employees and drivers of Erzurum Forest Nursery Directorate face dangerous situations less in terms of working environments than physical workers. Here, the group that must be examined is the body workers. The dangerous situations body workers face in the work environment are more than the other groups. For example, the risk levels of a person who works in pruning and the risk level of a person who works at a desk in an office are different. For this reason, the fact that a significant relation was detected between the work done de facto and the safety measures in the Chi-Square Test, which shows that this issue should be paid attention. The answer that was given by the employees to the question "Are adequate security measures taken in the unit where you work?" comes to the forefront in this respect. The rate of the employees who did body works and who said "No" was $66.7 \%$ among the employees that said "No". This rate is very high compared to the $20.6 \%$ rate in the overall average.

The relation between the work done and health problems was examined, and a statistically significant relation was detected. In this respect, $79.4 \%$ of the employees said "No" to the question "Do you have any health problems that you think stem from nursery work?"; and 20.6\% said "Yes". Here, $20.6 \%$ of $84.6 \%$ who said "Yes" were physically employed. The high rates of the employees who did body works and who said "Yes" to the question "Do you have any health problems that you think stem from nursery work?" means that this is a negative situation that is worth to investigate. This is a very important finding for determining and following-up the occupational diseases at workplaces by doctors who work in these workplaces.

The relation between educational status and OHS basic education was examined; and a statistically significant relation was determined. In this respect, it was determined that $82.4 \%$ of the participants said "Yes" to the question "Have you received basic education on occupational health and safety?", and 17.6 said "No". Here, the entire postgraduate and doctorate groups and most of the faculty groups said "Yes". The highest rate in the respondents is in the secondary education and literate group. The rate of those who said "No" at secondary education level was $50 \%$. It is considered that the reason may be that the employees who were from secondary education level and who were literate were preferred in jobs other than nursery; and that there were employees who were off duty on the given date caused this situation. Organizing the training programs in a planned and announced manner can reduce this rate. One of the main mandatory provisions of the OHS Law 6331 is to provide OHS basic training in hours and periods that are proper for the danger class of all employees without considering the danger class.

As a result of the present study, it was determined that approximately half of the employees did not have job descriptions. This situation poses a contrary situation to the 
labor legislation and CLS in the workplace. It is a legal liability that administrations make the job descriptions of all employees as soon as possible, and make a notification to relevant employees concerned.

It was observed that those who had worked for more than 15 years had more health problems compared to those who had worked less. It is considered that this is because of the fact that employees face more health problems with their furthering age. It is stated in the relevant article of the CLS that is in force that those who work bodily for more than 15 years must be employed in lighter jobs. In case this is applied, it is considered that such employees will be less affected by health problems.

It may be seen more probable that nursery employees experience occupational diseases rather than occupational accidents. They may especially face disorders like muscular joint disorders. It is possible to reduce these diseases to acceptable levels with relevant preventive measures. The measures that will be taken must be determined by a risk assessment report that will be prepared by a commission that will be formed by employers or their representatives. For example, ergonomics trainings may be provided to employees for the solution of this issue. Mechanical and automatic systems may be established to improve thermal comfort conditions. Suitable personal protective equipment may be provided to employees in this context. Such measures may be diversified and multiplied by the abovementioned commission. In addition, it is considered that the KKDs of the employees at the primary and secondary level are unsuitable; and that the rate of occupational accidents will be higher for this group. This situation may be associated with the fact that such employees work in jobs that require body strength, which constitutes the risk of occupational accidents. Again, it may be possible to decrease the risk to an acceptable level with preventive measures in this respect. Dangerous situations faced by employees included in this category must be eliminated with priority. If such situations cannot be eliminated, the source of the danger must be eliminated. Here, engineering and managerial methods must be used. And finally, employees must be made to use appropriate KKD.

In the forestry sector, it is extremely important that legal arrangements are made to ensure that occupational health and safety services are performed in a conscious manner, and that relevant regulations that will cover all the regulations and working conditions are issued and implemented (Tunay and Emir, 2015).

It is considered that the fact that the rate of those who considered that the OHS trainings had positive contributions in the work life and that the rate of those who thought that work accidents and occupational diseases decreased after the implementation of Law 6331 was determined to be $88.2 \%$ shows that the implementations of the law was perceived well by employees and had a good impact on their conscious levels.

\section{Conclusion}

The aim of the present study was to evaluate the effects of Occupational Health and Safety Law (OHS) on forest nursery workers in Erzurum Forest Nursery Directorate. OHS is aimed to permanently improve the health and safety of workers. This matter is supported by the state with national strategy and policies.

Participation of workers to OHS administration (OHSA) was included in many OHSA standards and guidance. OHSA models should emphasize the active participation of workers as a critical factor to improve OHS performance (Walter and 
Frick, 2000). Empowering of workers and giving them feeling of autonomy and control are the important factors in terms of OHSA success (Hale and Hovden, 1998). Nevertheless, properly training and informing of the workers, and giving them a chance to investigate the problems and communicate with each other's to provide active participation is necessary.

The study showed that the workers in forest nursery directorate had enough knowledge about OHS and OHS applications were properly conducted based on laws. The use of personal protective equipment and periodical training of the workers are also in important matters regarding OHS. Raising the awareness of workers with regard to OHS culture, precautions improving their safety and health, and encouraging workers to communicate with administrators regarding OHS problems and risks which they observe and encounter are suggested. All demands from workers should be evaluated and taken due precautions.

As a result, it should be concentrated on training and educations regarding OHS to get better results and provide the workers a better environment not adversely affect their physical and mental health.

\section{REFERENCES}

[1] Acar, H., SSentürk, N. (1997): A Research on the Health of Workers in Forest Workers in Yusufeli and Iskenderun Region İ.Ü. - Journal of Faculty of Forestry, Series: A, 47(2): 95-109. İstanbul.

[2] Bayılmış, O. Ü. (2013): Occupational Health and Safety Awareness Assessment: Fieldwork for Health Workers. - Master's Thesis. Y. Ü. Social Sciences Institute, 94 s. Yalova.

[3] Ekin, A. (2009): Occupational Health and Safety Obligations of the Employer. - Master's Thesis. S. Ü. Social Sciences Institute. 126 s. Konya.

[4] Engür, M. O. (2014): Training of Employees in Wood Production. Woodcutting and Lengthing Operator. - Forest General Directorate ve İ.Ü. Faculty of Forest. ISBN No:978-605-4610-53-2 S. 393, Ankara.

[5] Frick, K., Wren, J. (2000): Reviewing occupational health and safety managementMultiple roots. - Amsterdam: Elsevier.

[6] GDF (2018): Forestry Statistics 2018. - RAR archive-Access 02.02.2019.

[7] Hale, A. R., Hovden, J. (1998): Management and culture: the third age of safety. A review of approaches to organisational aspects of safety, health and environment. Occupational Injury. Risk Prevention and Intervention: 129-165.

[8] Kılıç, M. (2006): The Legal Status Of The Agricultural Workers Under The New Labor Law No. 4857. - Ankara University Faculty of Agriculture Journal of Agricultural Economics 12(2): 39-49.

[9] Menemencioğlu, K. (2006): A Study on Working Conditions and Work Accidents in Forestry Production Works. - Journal of Faculty of Forestry. Series: A, Number: 2, ISSN: 1302-7085, Sayfa: 1-12, Isparta.

[10] Oğuz, Ö. (2010): Obligations of Employers and Workers' Rights in Occupational Health and Safety in Turkish Labor Law. - PhD Thesis. A.Ü. Social Sciences Institute, Eskişehir.

[11] Poschen, P. (1993): Forestry, A Safe and Healthy Profession. - Unasylva 44(1): 172.

[12] TUIK (2018): https://itspopulation.com.-Access: 27.01.2019.

[13] Tunay, M., Emir, T. (2015): Evaluation of occupational health and safety in the legal framework of forestry production. - Turkish Journal of Forestry 16(2): 195-202. Isparta. 
[14] Walter, D., Frick, K. (2000): Workers participation and the management of occupational health and safety; reinforcing or conflicting strategies. - Amsterdam: Pergamon.

[15] Zorlu, V. A. (2008): Occupational health and safety measures in terms of human resources and a research on the subject. - Master Thesis, İ. Ü. Social Sciences Institute, 178 s.İstanbul. 